\title{
Harian Rakjat "Mengangkat" Suara dari Bawah: Rubrik Asmu Menjawab dalam Pemberitaan Suara Petani Terkait Kasus Landreform 1961-1965
}

\author{
Bambang Rakhmanto \\ Magister Ilmu Sejarah, Fakultas Ilmu Budaya, Universitas Indonesia \\ *Penulis Korespondensi: bambang.rakhmanto@gmail.com
}

\begin{abstract}
This article discusses the role of Harian Rakjat to established public opinion via citizen journalists. It aimed to seek sympathy from the peasants when implemented land-reform policies as stipulated in the Basic Agrarian Law (UUPA). The discussion was carried out by examining the articles of the resident that reviewed responded the issue of land ownership in the column of Asmu Menjawab. By using the historical method and applying discourse analysis theory, this study succeeded to find the implementation of land reform policies reaped many pros and cons among the community. The implementation of land reform in Java according to the testimonies was then used by the Indonesian Communist Party (PKI) as political propaganda in its practical politics.
\end{abstract}

Diterima/ Received: 29 Juni 2018

Disetujui/ Accepted: 28 September 2018
Keywords: Harian Rakjat, Landreform, Asmu Menjawab.

\section{Abstrak}

Artikel ini membahas tentang peranan Harian Rakjat dalam membangun opini publik melalui citizen jurnalist guna mencari simpati kaum tani ketika penerapan kebijakan landreform yang diatur dalam Undang-Undang Pokok Agraria (UUPA). Pembahasan dilakukan dengan mencermati tulisan-tulisan dari warga yang mengulas isu pengaturan kepemilikan tanah atau landreform dalam kolom Asmu Menjawab. Dengan menggunakan metode sejarah dan menerapkan teori analisis wacana, kajian ini berhasil menemukan bahwa penerapan kebijakan landreform banyak menuai pro dan kontra di kalangan masyarakat. Pelaksanaan landreform di Jawa berdasar kesaksian para penulisnya itu kemudian dimanfaatkan oleh Partai Komunis Indonesia (PKI) sebagai propaganda politik dalam politik praktisnya.

Kata Kunci: Harian Rakjat; Landreform; Asmu Menjawab.

\section{Pendahuluan}

Berbagai konten tersaji dalam sebuah surat kabar di awal Demokrasi Terpimpin yaitu pada 1959. Koran yang saat itu mayoritas milik partai politik menyajikan berita aktual, dan menampilkan kolom untuk tulisan dari warga, atau yang sekarang akrab dengan istilah citizen jurnalis. Beberapa media menyediakan kolom itu untuk 
menampung tulisan dari masyarakat. Sekadar sebagai contoh adalah Suluh Indonesia. Koran ini memiliki kolom bernama Pembaca Menulis (Suluh Indonesia, 10 Oktober 1961). Sementara itu, koran Duta Masjarakat, koran yang dimiliki Partai Nahdatul Ulama ini juga menerima tulisan-tulisan dari warga dalam kolom Tanya Jawab Keagamaan oleh Abu Macmoun. Dalam kolom ini pembaca dipersilakan untuk menanyakan permasalahan yang ada di sekitar mereka dan akan diberikan solusi sesuai dengan ajaran Islam (Duta Masjarakat, 27 Juli 1962).

Salah satu pendorong kemunculan kolom berita dari warga adalah mulai meningkatnya kemampuan membaca dan menulis yang dimiliki warga. Data itu terungkap dari sensus yang dilakukan pada 1961 sebagaimana tersaji pada Tabel 1.

Tabel 1. Persentase Penduduk Indonesia Melek Huruf 1961

\begin{tabular}{ccccc}
\hline \multirow{2}{*}{ Umur } & \multicolumn{2}{c}{ Pria } & \multicolumn{2}{c}{ Wanita } \\
& Kota & Pedesaan & Kota & Pedesaan \\
\hline $10-14$ & 89,8 & 73,5 & 84,7 & 64,0 \\
$15-19$ & 92,3 & 72,9 & 79,9 & 54,3 \\
$20-24$ & 89,0 & 70,2 & 64,4 & 40,1 \\
$25-34$ & 79,2 & 58,5 & 47,8 & 26,9 \\
$35-44$ & 74,3 & 49,4 & 37,1 & 18,2 \\
$45-54$ & 65,1 & 38,2 & 24,2 & 9,4 \\
$55-64$ & 57,7 & 29,0 & 17,5 & 6,1 \\
$65-74$ & 50,6 & 20,6 & 12,2 & 5,0 \\
$75+$ & 40,7 & 21,3 & 9,5 & 6,0 \\
\hline
\end{tabular}

Sumber: Keyfitz dan Nitisastro, 1961: 150.

Koran lain yang fokus menampilkan kolom untuk tulisan dari warga adalah Harian Rakjat. Harian milik Partai Komunis Indonesia (PKI) (Donald, 1966: 63; Firdaus, 2017: 5) sejak 31 Oktober 1953 ini banyak memuat tulisan-tulisan dari masyarakat. Dalam rangka menyerap aspirasi kaum buruh, Harian Rakjat menerjunkan korespondennya. Para kader dan aktivis serikat buruh diminta untuk mengirim berita, dan beritanya dimuat di dalam kolom Berita Daerah. Ketua Dewan Redaksi Harian Rakjat Njoto mengklaim kekuatan dan yang menjadi pembeda Harian Rakjat dengan koran-koran lainnya adalah adanya tulisan dari Citizen Journalist. Berita yang dikirim oleh koresponden diberi tanda Korbu, singkatan dari Koresponden Buruh. Sementara itu, berita-berita yang berasal dari kaum tani diberi tanda Korta, kependekan dari Koresponden Tani (Njoto, 1958: 19).

Salah satu kolom yang memuat tulisan dari para warga di koran nasional ini diberi judul Asmu Menjawab. Kolom ini dibuat untuk menyukseskan kebijakan landrefrom sesuai dengan kepentingan PKI (Anonim, 1960: 3). Tata cara pelaksanaan Landreform tertuang dalam Undang-Undang Pokok Agraria atau yang dikenal dengan UUPA No. 5 Tahun 1960. Latar belakang Presiden Soekarno menerbitkan UndangUndang tersebut untuk pemeratan kepemilikan tanah di masyarakat. Hal itu tercantum dalam UUPA pasal 7; untuk tidak merugikan kepentingan umum, maka 
pemilikan dan penguasaan tanah yang melampaui batas tidak diperkenankan. Dari rubrik ini PKI memengaruhi para pembacanya untuk menentang para pemilik lahan. Puncaknya adalah pada gerakan aksi sepihak yang berlangsung pada 1964-1965.

Berdasar uraian di atas, permasalahan utama yang dikaji dalam artikel ini adalah mengenai peranan Harian Rakjat dalam menyuarakan suara petani dalam permasalahan landreform 1961-1965 melalui rubrik Asmu Menjawab. Adapun pertanyaan penelitian yang diajukan meliputi alasan landreform menjadi isu penting pemberitaan di media cetak masa itu, peranan rubrik Asmu Menjawab untuk menggambarkan kasus landreform tersebut, dan dampak dari kritik Asmu menjawab yang dikirimkan oleh masyarakat. Pertanyaan tersebut merupakan satu kesatuan dalam upaya memecahkan permasalahan mengenai peranan Harian Rakjat dalam menyuarakan sekaligus mencari massa dari kalangan petani melalui kasus-kasus landreform dan pembagian bagi hasil lahan pada masa awal Demokrasi Terpimpin melalui rubrik Asmu Menjawab.

Artikel ini bertujuan untuk memberikan gambaran bagaimana Harian Rakjat dalam membangun opini publik melalui citizen jurnalis guna mencari simpati kaum tani dengan cara mendukung mereka mendapatkan lahan. Selain itu, isu landreform merupakan salah satu peristiwa sejarah yang besar dari peristiwa-peristiwa lainnya yang terjadi di masa lalu. Walaupun sudah banyak penelitian yang mengangkat isu kepemilikan lahan yang memicu gerakan sepihak oleh para kaum tani ini, namun belum ada yang mengangkat peranan media dalam memotret dan menyajikan permasalahan landreform dalam pemberitaanya. Harian Rakjat menjadi salah satu media yang serius dalam mengangkat isu tersebut.

Untuk membantu memecahkan permasalahan yang diangkat, penulis meggunakan teori sebagai alat bantu untuk menginterpretasikan atau mengolah data yang didapat. Dalam hal ini peneliti akan menggunakan metode analisis wacana untuk menganalisis makna tulisan-tulisan yang disampaikan oleh para petani. Fairclough (1955) seorang ahli analisis wacana, mendasarkan pada pertanyaan besar, bagaimana menghubungkan teks yang mikro dengan konteks masyarakat yang makro. Fairclough berusaha membangun suatu model analisis wacana yang mempunyai kontribusi dalam analaisis sosial dan budaya, sehingga ia mengombinasikan tradisi analisis tekstual yang selalu melihat bahasa dalam ruang tertutup, dengan konteks masyarakat yang lebih luas. Titik perhatian besar dari Faircolugh adalah melihat bahasa sebagai praktik kekuasaan. Fairclough membagi analisis wacana dalam tiga dimensi: teks, discourse practice, dan sociocultural practice (Fairclough, 1955: 24).

\section{Metode}

Metode yang digunakan untuk merekonstruksi sejarah pers tentang peranan Harian Rakjat dalam menanggapi kasus-kasus Undang-undang bagi hasil yang mengatur Landreform ini adalah metode sejarah yang terdiri atas empat tahap. Pertama adalah tahap heuristik; pada tahap ini penulis mengumpulkan bahan atau sumber-sumber yang relevan. Sumber-sumber itu mencakup sumber primer dan sekunder. Di antara 
sumber primer yang penulis peroleh adalah berupa koran Harian Rakjat. Dalam penelitian lebih lanjut, penulis mendapatkan bahan-bahan sezaman melalui koleksi Perpustakaan Nasional Republik Indonesia di Salemba Jakarta, bagian surat kabar langka. Di samping itu, penulis juga menggunakan sumber primer lainnya, seperti buku-buku yang ditulis oleh pelaku dan saksi sejarah. Sementara itu, dalam pencarian sumber sekunder, penulis berusaha mencari tulisan yang membahas tentang Harian Rakjat. Penulis juga menemukan beberapa lembar arsip mengenai pers dalam kurun waktu tersebut, dan Undang-Undang No. 2 Tahun 1960 tentang Perjanjian Bagi Hasil ketika berkunjung untuk melakukan penelitian di Arsip Nasional Republik Indonesia (ANRI) di Ampera Jakarta Selatan.

Selain menggunakan data tertulis sebagai sumber sejarah penulis juga menggunakan sumber lisan yang diperoleh melalui wawancara terhadap orang-orang yang pernah terlibat di dalam Harian Rakjat (Kuntowijoyo: 1994: 24). Setelah data berhasil dikumpulkan, kemudian melangkah ke tahap yang kedua, yaitu kritik. Tahap kritik terbagi ke dalam kategori, yaitu kritik eksternal dan internal. Oleh karena sumber-sumber diperoleh dari lembaga-lembaga negara yang memiliki otoritas dalam penyimpanan sumber sezaman, maka kritik ditekankan pada kritik internal, yaitu melakukan perbandingan (uji silang) dari beberapa sumber yang ditemukan seperti buku dan karya-karya tulis lainnya. Tahap selanjutnya adalah interpretasi, yaitu upaya untuk menganalisis masalah yang menjadi fokus perhatian dengan menerapkan pendekatan sebagai suatu pisau analisis; yang dalam hal ini adalah analisis wacana. Tahap yang keempat dan terakhir, yaitu tahap penulisan sejarah atau rekonstruksi. Pada tahap ini penulis menyusun fakta-fakta yang telah dianalisis menjadi sebuah tulisan sejarah.

\section{Rubrik Asmu Menjawab}

Kolom Asmu Menjawab mulai diterbitkan pada 17 April 1961 kepada para pembaca Harian Rakjat. Rubrik ini dikeluarkan tujuh bulan setelah UUPA yang mengatur kebijakan landrefom diresmikan oleh Presiden pada September 1960. Asmu Menjawab bertujuan untuk melayani pertanyaan dari para pembaca yang ingin menanyakan seputar landrefom dan Undang-Undang Bagi Hasil (UUBH). Asmu Menjawab diterbitkan setiap hari Senin dan Kamis. Asmu mengajak para petani untuk tidak menggantungkan diri kepada para penguasa atau tuan tanah. Para petani sendiri yang akan mengambil peran serta guna memperoleh hak-hak itu dengan tangan mereka sendiri (Harian Rakjat, 9 Mei 1961).

Dalam tulisan-tulisan yang dikirimkan ke Redaksi Harian Rakjat untuk kolom Asmu Menjawab terungkap kemacetan-kemacetan pelaksanaan UUPA dan UUBH yang terjadi hampir di setiap desa. Orang-orang yang melaporkan lewat tulisannya beragam. Mereka yang mengirim tulisan di antaranya orang biasa dalam hal ini bukan petani, tetapi mengetahui permasalahan landreform di sekitarnya; petani; dan aktivis. Para aktivis atau pun anggota Barisan Tani Indonesia (BTI) biasanya agar tulisannya 
dimuat, tulisannya diberi stempel oleh perwakilan BTI yang ada di sekitarnya. Oleh karena itu, sangat sulit untuk membedakan antara tulisan petani dan aktivis . ${ }^{1}$

Tulisan-tulisan dari warga yang dicetak di Asmu Menjawab banyak yang menyampaikan hambatan-hambatan dalam pelaksanaan landreform dan UUBH. Untuk menganalisis makna tulisan-tulisan yang disampaikan warga dapat menggunakan analisis wacana dari Fairclough seorang ahli analisis wacana. Dia mendasarkan pada pertanyaan besar, bagaimana menghubungkan teks yang mikro dengan konteks masyarakat yang makro. Fairclough berusaha membangun suatu model analisis wacana yang mempunyai kontribusi dalam analisis sosial dan budaya, sehingga ia mengkombinasikan tradisi analisis tekstual yang selalu melihat bahasa dalam ruang tertutup, dengan konteks masyarakat yang

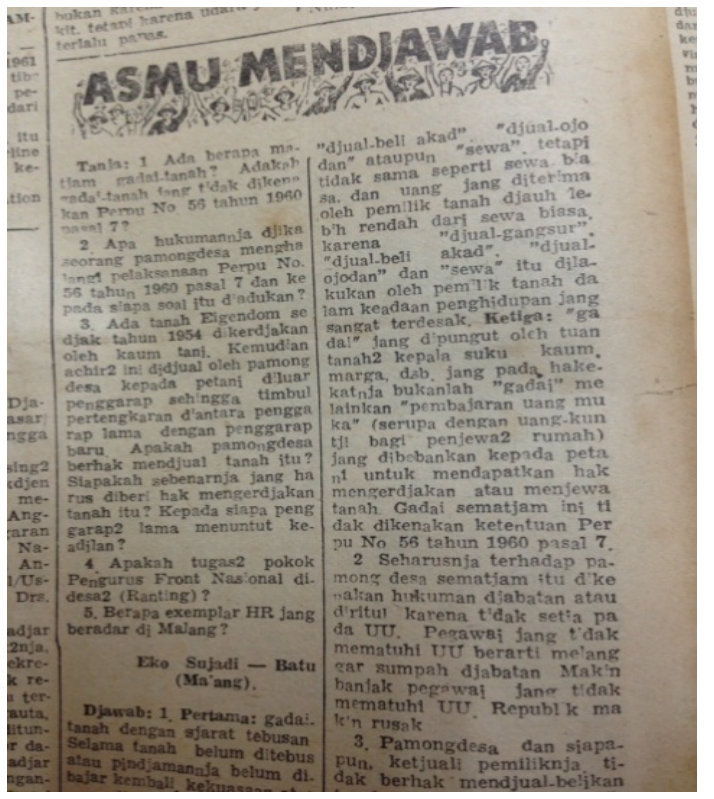

Gambar 1. Rubrik Asmu Menjawab Sumber: Harian Rakjat, 11 September 1961. lebih luas. Titik perhatian besar dari Faircolugh adalah melihat bahasa sebagai praktik kekuasaan. Teks di sini dianalisis secara linguistik, dengan melihat kosakata, semantik, dan tata kalimat ia juga memasukkan koherensi dan kohesivitas, bagaimana antarkata atau kalimat tersebut digabung, sehingga membentuk pengertian. Semua elemen yang dianalisis tersebut dipakai untuk melihat tiga masalah berikut: pertama ideasional yang merujuk pada representasi tertentu yang ingin ditampilkan dalam teks, yang umumnya membawa muatan ideologis tertentu. Sociocultural Practice adalah dimensi yang berhubungan dengan konteks di luar teks. Konteks di sini memasukkan banyak hal, seperti kontesks situasi, lebih luas adalah konteks dari praktik institusi dari media sendiri dalam hubungannya dengan masyarakat atau budaya dan politik tertentu. Misalnya politik media, ekonomi media, atau budaya media tertentu yang berpengaruh terhadap berita yang dihasilkannya (Eriyanto, 2012: 285).

Berdasar teori tersebut Harian Rakjat yang merupakan media PKI sangat terpengaruh dengan arah kebijakan dan tujuan partai, yang dalam persoalan landreform Harian Rakjat memposisikan diri berada di belakang kaum tani dan berseteru dengan para tuan tanah. Sehubungan dengan itu, tulisan-tulisan yang dimunculkan dalam kolom Asmu Menjawab adalah tulisan-tulisan yang sesuai dengan kepentingan partai dan kaum tani. Tulisan-tulisan para pembaca disesuaikan juga dengan kondisi sosial ekonomi di lingkungan mereka. Pengkelasan sosial di pedesaan didasarkan atas seberapa besar ia menguasai tanah. Menurut keadaan pertanian di

${ }^{1}$ Wawancara dengan Martin Aleida (74 Tahun), pekerja di Harian Rakjat dari tahun 19601965, di Dewan Kesenian Jakarta, pada 11 Desember 2017 
Jawa, dapat dibedakan kelas-kelas sosial adalah tuna tanah, petani kaya, petani miskin dan buruh tani (Rachman, 2004: 125).

\section{Hambatan Landrefom}

Selama penerbitan Rubrik Asmu Menjawab kurang lebih hampir tiga tahun terkumpul sekitar 119 laporan dari pembaca mengenai perkembangan pelaksanaan landreform (Anonim, 1964: 1). Dalam tulisan-tulisan warga ini terungkap adanya ganjalan atau hambatan dalam pelaksanaan landreform di sekitar tempat tinggal mereka.

Salah satunya dari Kanaan, asal Bojonegoro, Jawa Timur. Dia menyampaikan melalui tulisannya yang dikirim ke rubrik Asmu Menjawab, bahwa di daerahnya landreform masih belum dapat dirasakan masyarakat, karena belum terbentuk panitia pelaksana landreform. Warga juga kurang mendapat informasi kepada siapa mereka harus meminta agar panitia landreform dapat terbentuk dan berjalan, karena salah satu syarat terlaksananya program ini adalah terdapat panitia yang akan mendata tanahtanah berlebih yang akan dibagikan ke warga (Harian Rakjat, 20 Juli 1961).

Selain itu, masalah landreform yang diungkapkan pembaca antara lain masih banyak pembaca yang masih belum mengetahui cara pelaksananaan landreform. Informasi yang masih belum mengalir ke masyarakat menjadi salah satu penyebab kebijakan pemerintah ini menjadi tersendat. Bakri asal Tegal, Jawa Tengah misalnya, menanyakan penggarap mana yang mendapat prioritas untuk memperoleh tanah lebihan dari para tuan tanah. Dia juga menyampaikan apakah tuan tanah boleh mengusir kaum tani penggarap dari tanah yang telah diberikan. Selain itu, dia juga menanyakan apa konpensasinya bagi petani yang telah mendapat tanah itu. Menanggapi pertanyaan itu, Asmu Menjawab memberikan keterangan, bahwa petani yang mendapat prioritas adalah petani yang menggarap tanah milik tuan tanah yang tanahnya melebihi batas maksimum. Asmu juga menegaskan pemberian tanah ini tidak cuma-cuma, karena kaum tani yang mendapat bagian tanah memiliki kewajiban setelah dua tahun kepemilikan tanah. Setiap tahun kaum tani yang mendapat bagian tanah harus mencapai kenaikan hasil sebanyak yang ditetapkan oleh Dinas Pertanian Rakjat Daerah yang diatur dalam PP No. 224 tahun 1961 pasal 14 ayat 5 (Harian Rakjat, 10 Juni 1963).

Asmu Menjawab mendesak pelaksana landreform UUPA dan UUBH. Ia juga menuntut agar UUPA dan UUBH beserta peraturan turunannya dilaksanakan dengan konsekuen, serta mendesak pembentukan pemerintahan daerah swatantra tingkat III secara demokratis sebagai pengganti pemerintahan desa warisan kolonial. Tanah mereka jatuh ke tangan negara tanpa ganti rugi untuk dibagikan kepada petani dan pemiliknya dipidana dengan hukuman kurungan selama-lamanya tiga bulan dan atau denda sebanyak-banykanya Rp. 10.000. Dalam desakannya itu, Asmu Menjawab juga meminta pelaksana UUPA dan UUBH memerhatikan Peraturan Pemerintah No. 224 Tahun 1961 pasal 19 dan UU No. 56 Prp Tahun 1960 pasal 10 (Harian Rakjat, 5 Juli 1962). 


\section{Menebar Kebencian}

Asmu Menjawab digunakan PKI untuk menebar kebencian kepada para pemilik lahan. Dalam rubrik ini Asmu mengajak masyarakat untuk menentang para tuan tanah. Selain itu, Sukodadi asal Lamongan Jawa Timur juga menanyakan hasil konkret di daerah percontohan landreform Dst II Karawang seperti yang dinyatakan dalam Keputusan Menteri Agraria 5 Juni 1961. Cepat atau lambatnya pelaksanaan peraturan ini banyak tergantung pada kekuatan aksi-aksi kaum tani dan kesungguh-sungguhan panitia landreform Dst II yang oleh peraturan tersebut diberi banyak wewenang untuk menguasai dan membagikan tanah-tanah kelebihan dari batas maksimum dan tanahtanah lain (Harian Rakjat, 19 Desember 1961).

Musuh BTI dan kaum tani hanya tiga, yaitu: imperialis; tuan tanah dan kaum komprador, yaitu kaum borjuis yang hidup semati dengan kaum imperialis; dan pamong desa yang berkedudukan sebagai tuan tanah atau bertindak menindas kaum tani dan memusuhi BTI. Sebenarnya pamong desa bukan musuh BTI dan kaum tani. Biasanya, pamong desa yang menjadi musuh BTI dan kaum tani adalah pamong desa yang menempatkan dirinya ke dalam kubu musuh kaum tani dan revolusi, menjadikan dirinya anti-Manipol, Djarek, dan Resopim. Pamong desa yang bukan tuan tanah yang demokrat dan patriotik yang manipolis adalah sahabat BTI, sahabat kaum-kaum tani (Harian Rakjat, 21 Desember 1961).

Slogan tanah untuk tani juga diselipkan Asmu Menjawab dalam tulisannya seperti pada edisi pertengahan September 1961. Dalam menjawab pertanyaan dari Sujoto asal Klaten, dia bertanya mengenai bagi daerah yang sangat padat penduduknya, apakah peraturan batasan maksimum masih berlaku apakah sebaiknya diberlakukan peraturan khusus, apakah seseorang boleh memiliki tanah yang terpencar-pencar di beberapa daerah tingkat II asal tidak melebihi batas maksimum? Di dalam jalannya revolusi kita diterangkan, bahwa tanah untuk tani. Berhubung dengan itu apakah orang-orang bukan petani seperti pegawai negeri, pekerja-pekerja kerajinan tangan yang memiliki tanah harus melepaskan tanahnya.

Semboyan tanah untuk tani adalah tepat dan benar-benar merumuskan tuntutan pokok kaum tani. Akan tetapi, semboyan itu belum terlaksana. Semboyan itu pasti akan terlaksana yaitu sesudah modal kekuasaan monopoli asing atas ekonomi negeri kita dihapuskan dan penghisapan tuan tanah-tuan tanah feodal atas kaum tani diakhiri. Pada saat itu perjuangan kaum tani ditujukan untuk membatasi monopoli tanah dan penghisapan feodal dari para tuan tanah, pegawai-pegawai negeri, pekerjapekerja kerajinan tangan, dan sebagainya. Berdasar Undang-undang masih diperbolehkan memiliki tanah asal tidak melebihi batas maksimum. Jika tanah mereka disewakan supaya sewa tanah diturunkan sesuai dengan ketentuan UUBH (Harian Rakjat, 14 September 1961).

\section{Aksi Sepihak}

Pada akhir 1963 mulai tampak di mata para pengurus PKI dan organisasi petani yang dilimiliki oleh PKI (BTI) mengenai kemacetan-kemacetan landreform yang diungkap dalam kolom Asmu Menjawab. Setelah itu, PKI dan BTI mengubah pola gerakan. 
Sidang pleno CC PKI bulan Desember 1963 menuntut agar landreform dilaksanakan secara radikal. Tanah-tanah milik para tuan tanah harus disita tanpa ganti rugi. PKI mengklaim, dari 1.000.000 hektare tanah lebih, baru terdaftar sekitar 200.000 hektare. Dari jumlah itu baru 9\% yang dibagikan kepada kaum tani. PKI juga membela, mendukung, serta menganjurkan aksi-aksi sepihak oleh para pertani terhadap segala bentuk sabotase dan permainan pada pelaksnaan landreform (Aidit, 1964: 15).

Langkah PKI dan BTI untuk melaksanakan aksi sepihak sudah lama dipersiapkan salah satunya dengan penerbitan rubrik Asmu Menjawab. Selama tiga tahun 1961-1963 rubrik ini mengkampanyekan UUPA dan UUBH. Selain itu secara energik AsmuMenjawab mengajak para petani untuk melawan para tuan tanah. Aksi Sepihak untuk mendobrak ketersendatan pelaksanaan UUBH-UUPA atau landreform terjadi di berbagai pedesaan. Aksi Sepihak dilancarkan sejak musim tanam tahun 1963-1964. Aksi sepihak banyak berlangsung di Jawa Timur dan Jawa Tengah. Hal ini sejalan dengan laporan dari para pembaca di Asmu Menjawab yang banyak berasal dari tempat tersebut. Salah satunya terjadi di Ketaon Banjudono-Boyolali, Jawa Tengah pada 23 Oktober 1964. Petani asal Boyolali, tuan tanah Kromosukarta memberi garapan atas sawahnya kepada Partowiredjo alias Walidi dengan cara lama. Setelah tanaman padi tua oleh penggarap dilaporkan kepada pemilik agar padi dipanen pada Jumat 23 Oktober 1964 dengan tuntutan bagi hasil dan penggarpan berikutnya tetap akan langsung dikerjakan. Oleh pemilik dijawab, bahwa menurut kepercayaan maneni padi pada Jumat itu tidak baik, maka pemilik meminta waktu panen diundur hingga Sabtu 24 Oktober 1964. Selain itu, berhubung ada peraturan bagi hasil, maka untuk panenan itu pemilik setuju dibagi hasil, tetapi untuk selanjutnya sawah akan digarap sendiri (Aidit, 1964: 15). Penggarap tidak dapat menyetujui keterangan pemilik seperti tersebut, kemudian pada 23 Oktober 1964 penggarap tetap memotong padi. Oleh pemilik aktivitas itu dapat dicegah. Pemilik kemudian melapor pada kelurahan dan kemudian pemilik bersama lurah desa meninjau sawah tersebut. Setelah tiba di sawah, pemilik dan lurah menjumpai orang-orang telah melanjutkan memotong padi (Setiawan, 2003: 6).

Sementara itu, di Jawa Timur gerakan aksi sepihak terjadi di sejumlah daerah seperti di Kecamatan Kencong, Kabupaten Jember; Kasus Garum, di Blitar; Umbulsari di Jember; dan pembelaan Imam Sardju, Ketua DPD BTI Jawa Timur terahadap kaderkader yang dianggap telah berjuang membela kepentingan kaum tani (Kasdi, 2001: 195). Pada September 1963 aksi sepihak meletus di Dukuh Sarinyono Desa Pedomasan Kecamatan Kencong Kabupaten Jember Jawa Timur. Para petani penggarap anggota BTI melancarkan aksi terhadap tanah milik Ny. Sudarno. Menurut pihak BTI tanah itu telah menjadi tanah lebih bekas milik Ny Sudarno. Sebelum terjadinya peristiwa itu pihak BTI telah memaksa Ny. Sudarno untuk menerima bagiannya seusai dengan ketentuan UUPA dan UUBH, tetapi gagal karena pihak pejabat desa dan kecamatan menolak pemaksaan itu. Namun demikan, para anggota BTI tidak peduli. Akibatnya lima orang penggarap ditangkap oleh kepolisian Kencong dengan tuduhan mengambil hak orang lain. Proses penahanan ke lima orang bekas penggarap itu diserahkan kepada Kejaksaan Negeri Jember (Terompet Masjarakat, 24 Januari 1964). 
Sejak dimulai aksi-aksi sepihak, terjadi pertentangan terbuka antara PKI/ BTI dengan lawan-lawannya, terutama para tuan tanah dan organisasi Islam. Peristiwa ini terjadi dan terus berkembang di Sidoarjo. Ketika Pemuda Rakyat Sidoarjo menyelenggarakan kegiatan ceramah pada Februari 1965, sekelompok pemuda tidak dikenal melemparinya dengan batu. Akan tetapi, pihak keamanan akhirnya dapat menemukan pimpinan organisasi pemuda setempat yang diduga menjadi otak pelemparan tersebut. Di Tanggulangin terjadi perkelahian antara massa komunis dan para santri. Perkelahian itu terjadi karena PKI menuduh Madrasah Islam yang ada di tempat itu sebagai sekolah liar atau ilegal (Mortimer, 1972: 50). Suatu kejadian aksi sepihak juga menyebabkan terjadinya pemukulan terhadap anggota BTI oleh pejabat desa di Sidoarjo. Sidang perkara itu di Pengadilan Negeri Siodarjo dihadiri lebih kurang 5000 pengunjung. Mereka terbagi dalam tiga faksi yakni PKI, Partai Nasional Indonesia (PNI), dan NU yang saling bersiaga (Mortimer, 1972: 50).

Penyerobotan tanah juga terjadi di Kota Surabaya Jawa Timur, antara lain di Kampung Petemon. Dalam waktu singkat di atas tanah bekas milik Tjan Siong Goh di Petemon telah berdiri ratusan rumah. Dengan dalih rumah-rumah itu telah memenuhi peremajaan kota, BTI setempat menuntut agar walikota Surabaya, Murachman S.H., segera mengesahkannya sebagai tanah milik. Usaha itu sia-sia, karena pemerintah pusat memutuskan memberikan hak pakai bekas tanah milik Tjan Siong Goh itu kepada PT. Bagong Putra (Terompet Masjarakat, 17 Desember 1964).

Ribuan pemuda Ansor pada akhir 1964 dikerahkan ke tempat tinggal Kiai di Batuampar, dekat Pamekasan Madura. Pengerahan dilakukan karena ada desasdesus, bahwa PKI bermaksud menyerang kiai. Kiai Batuampar memang kaya sekali, ibaratnya sebagai raja kecil. Kiai Batuampar adalah ahli waris kramat yang dimakamkan di situ, Bujuk Syamsuddin. Kekayaan Kiai Batu Ampar sangat kontras sepanjang jalan menuju makam kramat Batuampar 1963 penuh dengan orang mintaminta. Mereka berasal dari masyarakat sekelilingnya. Untuk beberapa waktu terjadi ketegangan di sekitar Batuampar Pamekasan (Mortimer, 1972: 58).

\section{Respon Aksi Sepihak}

Aksi sepihak mendapat kecaman dari berbagai pihak, salah satunya NU. Ketua satu PP Pemuda Anshor Jusuf Hasjim menyatakan, bahwa pelaksanaan UUPA dan UUBH, ada dua musuh yang harus dihadapi dan diganyang Pemuda Ansor. Musuh-musuh itu menurut Jusuf Hasjim adalah kaum feodal dan kaum penipu tani yang disebutnya sebagai "setan tanah". Adapun kaum penipu ini adalah mereka yang sok membela kaum tani, berlagak sebagai pahlawan tani dan dengan segala macam tipu dayanya berhasil menarik kepercayaan kaum tani. Kaum penipu tani tidak segan-segan menghasut kaum tani untuk menyerobot tanah, menggarong perkebunanperkebunan milik orang lain, tanpa mempedulikan peraturan-peraturan yang berlaku (Duta Masjarakat, 19 Januari 1965).

Namun, gerakan ini juga mendapat dukungan di antaranya datang dari Menteri Kehakiman Astrawinata. Dia menyampaikan bahwa tindakan aksi sepihak yang dilakukan oleh kaum tani bisa dimengerti. Dia menjelaskan, bahwa aksi sepihak yang 
dilakukan oleh kaum tani di beberapa daerah di Indonesia itu disebabkan oleh kelambatan pelaksanaan landreform. Menurutnya, sebab-sebab tersendatnya pelaksanaan landreform adalah selain karena adanya simpatisan-simpatisan tuan tanah, juga di antara anggota panitia landreform itu sendiri ada yang memiliki tanah yang sebenarnya harus kena peraturan-peraturan dan undang-undang yang berlaku seperti UUPA dan UUBH (Antara, 1 Juli 1964).

Setelah aksi sepihak pecah di sejumlah daerah di Jawa Timur dan Jawa Tengah media-media yang semula diam mulai bersuara setelah tiga tahun Harian Rakjat melalui kolom Asmu Menjawab memprovokasi masyarakat. Salah satu media secara terbuka mengkritisi Harian Rakjat adalah Harian Merdeka pimpinan Burhanuddin Mohammad Diah atau yang dikenal dengan panggilan BM Diah. Perdebatan antarkedua media ini berlangsung lama pada Juli 1964. Merdeka membuat halaman khusus yang diberi judul "Mari Berjuang Benar-Benar untuk Kaum Tani.” Di halaman ini Merdeka mengkritik pemberitaan Harian Rakjat terkait aksi sepihak dan pelaksanaan landreform. Pada Merdeka edisi 2 Juli 1964 dimuat tulisan mengenai tanggapan Merdeka atas kritikan Harian Rakjat yang menyatakan Merdeka tidak mengerti permasalahan kaum tani. Merdeka menilai pemberitaan yang gencar terkait para petani merupakan bagian dari propaganda PKI.

Bung sebenarnya Merdeka bukan telah maju sedikit. Merdeka telah jauh lebih maju bahkan jauh lebih dari pada dugaan Harian Rakjat dalam memahami persoalan kaum tani. Hubungan-hubungan agraria di desa dan perjuangan kaum tani dan justru karena itu kita dengan pasti dapat mengatakan kepada Harian Rakjat bahwa aksi-aksi sepihaknya yang telah dilancarkan di Jawa Tengah itu bukan suatu aksi yang revolusioner dari kaum tani sebaliknya tani dipakai untuk mencapai suatu tujuan praktis PKI (Merdeka, 2 Juli 1964).

Selain itu, Merdeka meragukan berita Harian Rakjat. Merdeka meminta untuk dapat mengungkap tuan-tuan tanah yang jahat juga pejabat-pejabat yang protuan tanah yang tidak menjalani UUPA dan UUBH yang oleh Harian Rakjat selalu dikemukakan sebagai sebab timbulnya aksi sepihak. Harian Rakjat ditantang untuk munculkan fakta-fakta tersebut, terkait berapa jumlah tuan-tuan tanah dari jumlahnya yang tentu tidak sedikit itu membangkang terhadap undang-undang juga siapa-siapa dari pejabat pemerintah, jumlahnya dan dimana serta dimana terjadinya sabotase itu yang dilakukan oleh pejabat (Merdeka, 2 Juli 1964). Aksi sepihak tidak diragukan lagi merupakan tindakan kolektif dan spontan oleh petani. Namun demikian, tindakan spontan petani yang didaku disebabkan oleh situasi sosial ekonomi petani yang buruk digunakan oleh PKI untuk kepentingan politiknya sendiri (Merdeka, 3 Juli 1964).

Dalam edisi 2 Juli 1964, Merdeka mengkrtisi Harian Rakjat yang selalu memberitakan landreform yang tidak berjalan. Dalam edisi itu Merdeka menguraikan bahwa landereform fase satu yang baru diberlakukan di Jawa, Madura, Bali dan Nusa Tenggara Barat sudah berjalan. Panitia landreform telah bekerja menyelesaikan redistribusi tanah di beberapa daerah tingkat II bahkan sudah bergerak dalam bidang penertiban dan pengawasan untuk Jawa Barat dari luas 28.332 hektare tanah 
kelebihan maskimum yang terdaftar sudah diredistribusikan seluas 21.763 hektare dan yang menerima ada 29.190 orang petani. Sisanya 6.569 hektare terdiri atas tanahtanah tanaman keras yang dimintakan hak guna usaha tanah dalam sengketa tanahtanah yang letaknya belum dapat dipastikan dan tanah-tanah yang belum ada petani yang menginginkan seluas 2099 hektare. Di samping itu, ada 4.622 orang petani yang juga menerima 2.586 hektare tanah dari persediaan tanah-tanah Jawa Barat (Merdeka, 2 Juli 1964).

Di Jawa Tengah ada 3.987 orang pemilik tanah yang melaporkan kelebihan tanahnya dari maksimum luas seluruhnya ada 11.405 hektare dan dari jumlah ini 8.353 hektare telah selesai diredistribusikan kepada 14.527 orang petani tidak termasuk Pekalongan, Pemalang, Brebes, Cilacap, dan Temanggung. Dari sisa itu 3.052 hektare yang tidak atau belum dibagikan terdiri atas tanah-tanah wakaf, tanah sengketa, tanah warisan, tanah yang dalam perkara. Di samping itu, di Jawa Tengah juga telah dibagikan 73.761 hektare tanah yang berasal dari macam-macam tanah, bekas tanah partikelir, tanah absentee kepada 23.921 orang petani.

Di Jawa Timur ada 22.342 hektare tanah yang terdaftar sebagai tanah kelebihan maksimum. Tanah-tanah tersebut 5.683 hektare yang sudah selesai diredistribusi. Sisanya 16.659 hektare terdiri atas tanah-tanah yang ada di kepulauan serta tanahtanah dalam sengketa yang menurut rencana kerja panitia landreform akan diselesaikan pada 1964. Demikian angka-angka yang dikutip Merdeka dari publikasi panitia landreform pusat. Dari capaian itu dan dengan luasnya pekerjaan panitia, serta waktu yang singkat, tidak tepat jika pelaksanaan landreform dikatakan macet.

Untuk meredam gejolak yang terjadi di akar rumput, Presiden Soekarno memanggil 10 Pimpinan Partai ke Istana Bogor pada 12 Desember 1964. Para pemimpin partai yang datang di antaranya Ketua PNI Hardi S.H., Sekretaris Jenderal PNI Ir. Surachman, Ketua Umum NU Idam Chalid, Sekretaris Jenderal NU Aminudin Aziz, Ketua dan Wakil Ketua PKI D.N. Aidit dan M.H. Lukman. Dalam pertemuan itu para pemimpin partai yang hadir berkomitmen untuk mendukung penyelesaian permasalahan yang dihadapi pemerintah, di antaranya bertekad bulat untuk mendukung dan mengamalkan Pancasila, Manipol Usdek, dan pedoman-pedoman pelaksanaannya. Terkait pelaksanaan UUPA dan UUBH yang memanas di masyarakat desa, ke 10 Partai berkomitmen akan mengutamakan sistem konsultasi dan musyawarah yang dijiwai oleh semangat kegotongroyongan nasional Revolusioner berporoskan Nasakom (Deklarasi Bogor, 12 Desember 1964).

Usaha ini terbilang cukup berhasil meredam ekskalasi konflik, yang terbukti dari menurunnya tingkat aksi selama minggu-minggu pertama kesepakatan Deklarasi Bogor. Namun hal ini tidak mencegah tingkat ketegangan dan konflik yang telah terbentuk antara organisasi-organisasi di bawah pngaruh PKI dengan kalangan organisasi Islam. Di Jawa Timur, para pemimpin PNI yang sebelumnya bergabung bersama NU dalam menentang aksi sepihak mulai menarik jarak dengan dan menyerukan persatuan nasional setelah melihat gelombang perlawanan dan penentangan yang ditunjukkan oleh kelompok Islam menjadi semakin militan dan ekstrem (Mortimer, 1972: 56). 
Pada 20 Januari 1965, Presiden Soekarno dalam sidang DPA membentuk sebuah panitia perumus yang bertugas merumuskan pokok pembicaraan oleh 20 orang anggota DPA mengenai persoalan pelaksanaan landreform. Panitia tersebut diketuai oleh Dr. M. Tambunan S.H., sedangkan anggotanya terdiri atas Munir Bambang Murtijoso, Mayor Jenderal KKO Suhadi, Asmu, K.H. Farid Ma'Ruf, Tjilik Riwut, dan K. H. Idham Chalid. Dalam sidang DPA tersebut akhirnya ditetapkan suatu perumusan dan pertimbangan mengenai pelaksanaan landreform tanpa menimbulkan kekerasan (Duta Masjarakat, 23 Januari 1965). Ada 14 kesepakatan yang dihasilkan oleh para anggota perumus dari DPA. Tujuan dari usulan dari DPA ini agar pelaksanaan landreform berjalan lancar. Usulan-usulan tersebut di antaranya: menyelesaikan sengketa tanah melalui jalan musyawarah dengan mengutamakan sistem konsultasi dan musyawarah yang dijiwai oleh semangat kegotongroyongan revolusioner berporoskan Nasakom tanpa ada intimidasi dan senjata.

Namun demikian, usaha tersebut di lapangan tampaknya sulit untuk bisa berjalan dengan memuaskan. Picu yang telah ditarik melalui tindakan aksi sepihak di pedesaan Jawa tidak lagi dapat dikendalikan arahnya. Kegiatan Landreform dihentikan pada 26 Oktober 1965, oleh Menteri Agraria R. Hermanses S.H.. Pemberhentian ini dilakukan untuk menjaga ketertiban dan keamanan serta suasana ketenangan pada umumnya. Imbas dari aksi sepihak dan kekacauan politik yang ditimbulkan dari peristiwa G 30 S membuat suasana politik bergejolak. Berdasar Surat Keputusan Menteri Agraria No. 88/depag/1965, selain membekukan pelaksanaan landreform, Menteri Agraria juga menghentikan sementara semua kegiatan anggota-anggota panitia landreform di pusat dan daerah terutama panitia yang berasal dari Barisan Tani Indonesia.

\section{Simpulan}

Landreform menjadi penting untuk diberitakan karena terkait hajat hidup orang banyak. Lima belas tahun setelah Indonesia merdeka yaitu pada 1960, permasalahan kepemilikan tanah masih berlangsung. Mayoritas petani di Indonesia saat itu belum memiliki tanah. Kurang lebih $60 \%$ dari para petani adalah petani tidak bertanah. Sebagian mereka itu merupakan buruh tani, sebagian lainnya mengerjakan tanah orang lain sebagai penyewa atau penggarap dalam hubungan perjanjian bagi-hasil. Para petani yang mempunyai tanah (sawah dan/atau tanah kering) sebagian terbesar masing-masing tanahnya kurang dari 1 hektare (rata-rata 0,6 hektare sawah atau 0,5 hektare tanah kering) tidak dapat hidup secara layak. Kondisi inilah yang menjelaskan landreform merupakan isu yang seksi untuk diangkat oleh media, khususnya Harian Rakjat. Kebijakan pemerintah mengenai distribusi lahan pertanian dan telah diatur dalam UUPA ini belum berjalan sesuai dengan harapan. Hal itu yang menjadi fokus perhatian Harian Rakjat. Sejalan dengan tujuan PKI untuk mencari masa dari kaum tani yang jumlahnya besar, Harian Rakjat gencar memuat berita landreform. Harian Rakjat memberi ruang yang lebar untuk menyebarkan informasi seputar pembagian tanah berlebih ini. Selain memuatnya dalam lembaran berita, harian yang berjumlah empat halaman ini juga memberi ruang khusus yang diberi nama Asmu Menjawab. 
Kolom Asmu Menjawab sendiri yang menjadi bahan analisis dalam studi sejarah kali ini menggambarkan suatu fenomena isu landrefom bergejolak di kalangan masyarakat pedesaan. Pembaca yang berasal dari petani maupun para aktivis petani menyampaikan permasalahan landreform yang belum berjalan melalui tulisan yang mereka sampaikan di kolom Asmu Menjawab. Warga menulis berdasar pengalaman dan pengamatan di sekitar mereka. Dengan gaya bahasa warga yang apa adanya terungkap bahwa kebijakan landreform dan UUBH sejak diterbitkan belum dirasakan merata oleh masyarakat, karena menemui banyak hambatan.

Harian Rakjat memantau pelaksanaan program ini melalui kolom Asmu Menjawab. Seminggu dua kali BTI dan PKI mendapat laporan secara cuma-cuma dari warga mengenai perkembangan penerapan landreform di desa-desa. Para jurnalis warga inilah yang menjadi mata dan telinga PKI. Tulisan-tulisan warga yang diterima redaksi dimanfaatkan oleh oleh masyarakat untuk dapat menyampaikan pendapat dan kritiknya terhadap ketimpangan dan penyelewengan- penyelewengan seperti perilaku tuan tanah yang mulai marak terjadi pada masa tersebut. Pendapat dan kritik itu tidak hanya dilakukan melalui kolom Asmu Menjawab. Sebelumnya pada 1954 sampai 1957 Harian Rakjat juga memiliki kolom yang memuat berita dari warga yaitu Kolom Kita Dengar. Di kolom ini warga menulis berbagai persoalan yang mereka rasakan setiap hari di sekitar warga.

Asmu Menjawab diambil dari nama Sekretaris Umum BTI yang bernama Asmu. Selain memimpin organisasi yang berbasis masa petani ini dia juga menjadi penanggung jawab dari kolom Asmu Menjawab. Rubrik ini dapat diibaratkan seperti bahan bakar yang menyulut emosi warga selama tiga tahun. Sejak Asmu Menjawab dikenalkan kepada para pembaca pada April 1961 dan berhenti pada Juni 1963, selama kurun waktu itu Asmu terus melabeli tuan tanah sebagai orang yang jahat, dan orang yang selalu menindas kaum tani. Asmu juga menegaskan hubungan kerja yang bersifat penghisapan itu harus dilenyapkan. Para buruh, buruh tani, dan petani miskin oleh PKI didorong dan dibimbing untuk melakukan segala aksi menentang penghisapan dengan kekuatan mereka sendiri. Bertolak dari pemikiran ini, Asmu melalui tulisannya yang konsisten menyampaikan slogan-slogan seperti “tanah untuk petani, "upah yang menguntungkan buruh dan buruh tani", "bagi hasil yang menguntungkan petani penggarap".

PKI memanfaatkan rubrik ini sebagai alat untuk menjaring para simpatisan partai sebanyak-banyaknya. Landreform merupakan program dari PKI bersama BTI. Keduanya telah menentang tuan tanah sebelum UUPA disahkan. Perlawanan itu dibahas dalam Kongres PKI VI di Jakarta pada 12 September 1959. Dalam forum itu Asmu menyampaikan sebagai kewajiban yang pertama-tama bagi kaum komunis Indonesia. Untuk itu, tugas melenyapkan sisa-sisa feodalisme, mengembangkan revolusi agraria antifeodal, menyita tanah tuan tanah dan memberikan dengan cumacuma tanah tuan tanah kepada kaum tani, terutama kepada kaum tani tak bertanah dan tani miskin, sebagai milik perseorangan mereka, diterima oleh kongres sebagai kewajiban yang terdekat dari pada kaum komunis Indonesia dengan semobyan "tanah untuk kaum tani," 
Dengan demikian, walaupun PKI kerap menyerukan keberpihakannya terhadap rakyat dalam hal ini adalah petani, dan menyudutkan para pemilik tanah, dalam hal ini merupakan salah satu cara PKI untuk bisa mendapatkan massa seluas-luasnya. Sesuai dengan sifat media massa yang dibaca oleh masyarakat umum, diharpakan Asmu Menjawab menjadi media PKI untuk bisa mendekatkan Partai dengan para petani.

Asmu Menjawab menjadi sarana untuk mendorong gerakan petani yang dikenal dengan aksi sepihak. Asmu melalui tulisannya membakar semangat kaum tani untuk menjadi petani yang revolusioner dan berani menentang tuan tanah yang dianggapnya sering menindas para petani. Sebaran aksi sesuai dengan banyaknya laporan yang dimuat di Asmu Menjawab yaitu berada di sekitar Jawa. Mayoritas pusat gerakan aksi sepihak berlangsung di Jawa Timur, di antaranya Banyuwangi, Sambirejo Kediri, Bondowoso, Sidoarjo, Malang, dan Surabaya. Sementara itu, aksi sepihak di Jawa Tengah banyak terjadi di Boyolali.

Kondisi pemilikan tanah khususnya di Pulau Jawa dan beberapa daerah tertentu, telah mencapai tingkat kritis bagi timbulnya gejolak sosial yang kemudian dimanfaatkan oleh PKI untuk memasukkan ideologi politiknya ke dalam masalah itu melalui landreform dan permasalahan agraria lainnya. Walaupun demikian, partai itu dalam berbagai aksi sepihak yang dilancarkan gagal menarik seluruh lapisan buruh tani dan petani miskin dan mengikatnya ke dalam sebuah kelas proletar tidak bertanah di bawah pimpinan kaum buruh. Sebab kegagalan lainnya adalah karena masih kuatnya ikatan hubungan patron klien di berbagai aspek kehidupan di Jawa.

Aksi sepihak tidak lain merupakan politik praktis sebagai taktik perjuangan PKI melalui Harian Rakjat. Secara tidak langsung aksi sepihak telah menyebabkan kekeruhan dalam kerja sama partai-partai pendukung Nasakom yang sering digembar-gemborkan oleh Harian Rakjat dan kawan-kawannya. Namun, Harian Rakjat sendiri tidak mengakui adanya keretakan kerja sama itu. Dengan adanya aksi sepihak juga berimbas pada kerja sama partai-partai politik yang semula mendukung Nasakom.

Selain itu, pembunuhan masal terhadap para pengikut PKI setelah peristiwa G $30 \mathrm{~S}$, juga merupakan puncak kemarahan warga akibat aksi sepihak. Massa simpatisan PKI semenjak adanya aksi sepihak tidak disukai oleh warga yang tidak mendukung aksi sepihak di antaranya golongan santri dan simpatisan PNI. Sejak adanya aki sepihak kebencian warga terhadap para simpatisan PKI semakin tajam. Mereka ditanamkan untuk membenci orang-orang yang tidak sejalan dengan partai.

\section{Referensi}

Aidit (1964). Kobarkan Semangat Banteng!: Madju Terus, Pantang Mundur!. Jakarta: Jajasan Pembaruan.

Anonim (1958). Masalah-masalah Landreform jilid II. Jakarta: Jajasan Pembaruan. Anonim (1960). Beberapa Soal Mengenai Landreform. Jakarta. Departemen Penerangan. ANRI. Inventaris Arsip Komando Operasi Tertinggi 1963-1967. "Naskah Pidato DN Aidit pada Ulang Tahun ke- 44 PKI di Semarang", Reg. 101. 
ANRI. Inventaris Arsip Komando Operasi Tertinggi 1963-1967."Amanat P.J.M. Presiden Sukarno pada Resepsi Pembukaan Kongres Nasional ke VI BTI", Reg. 590.

ANRI. Inventaris Arsip Menko Hubra." Laporan Mengenai Aksi-Aksi Sepihak BTI “, Reg. 1968.

ANRI. Inventaris Sekertaris Negara RI 1945-1973. “ Manipol RI”, Reg. 2019.

Antara, 1 Juli 1964.

Donald, Hindley (1966). The Communist Party of Indonesia 1951-1963. California: California University Press.

Duta Masjarakat, Edisi 1961-1965.

Eriyanto (2012). Analisis Wacana Pengantar Analisis Teks Media. Yogyakarta: LKIS.

Firdaus, Fadrik Aziz (2017). Njoto Biografi Pemikiran 1951-1965. Tangerang Selatan: Marjin Kiri.

Harian Rakjat, Edisi 1961-1965.

Kasdi, Aminudin (2001). Kaum Merah Menjarah, Aksi Sepihak PKI/ BTI di Jawa Timur 1960-1965. Yogyakarta : Jendela.

Keyfitz, Nathan dan Nitisastro, Widjojo (1961). Soal Penduduk dan Pembangunan Indonesia. Jakarta: PT. Pembangunan.

Kuntowijoyo (1994). Metodologi Sejarah, cet. I. Yogyakarta: Tiara Wacana.

Merdeka, Edisi 2-3 Juli 1964.

Mortimer, Rex (1972). The Indonesian Communist Party \& Landreform 1959-1965. Victoria: Monash University.

Njoto (1958). Pers dan Massa. Jakarta: NV Rakjat.

Rachman, Noer Fauzi (2004). Petani dan Penguasa Dinamika Perjalanan Penguasa,. Jogyakarta: Insistpress.

Setiawan, H. (2003) Kamus Gestok. Yogyakarta: Galang Press.

Suluh Indonesia, Edisi 10 Oktober 1961.

Terompet Masjarakat, 24 Januari 1964 dan 17 Desember 1964. 